\title{
Adsorption Studies on the Removal of Fe(II) Ion onto Posidonia Oceanica Nano Carbon
}

\author{
S. SUMITHRA and S. ARIVOLI*
}

PG and Research Department of Chemistry, Thiru Vi Ka Government Arts College, Thiruvarur, Tamilnadu, India

arivu6363@gmail.com

Received 4 December 2016 / Accepted 21 December 2016

\begin{abstract}
Adsorption of Fe(II) ions by activated Posidonia oceanica nano carbon was studied by using batch adsorption techniques. The influence of contact time, initial concentration, dosage of adsorbent and effect of solution $\mathrm{pH}$ were investigated. The equilibrium adsorption data were correlated with Langmuir, Freundlich, Temkin, Dubinin-Radushkevich, Hurkins-Jura, Halsay, Radlich-Peterson, Jovanovic and BET isotherm models. The isotherm studies of $\mathrm{R}_{\mathrm{L}}$ values showed that the adsorption process was favorable. Thermodynamic parameters such as $\Delta \mathrm{H}^{0}, \Delta \mathrm{S}^{0}$ and $\Delta \mathrm{G}^{0}$ were evaluated. The data indicate that, the adsorption was spontaneous and is an endothermic nature. Adsorption kinetics was tested with pseudo- second-order, Elovich model and intra - particle diffusion models. Kinetic studies indicate an adsorption pseudo-second-order reaction. This study shows that intra-particles played a major role in the adsorption of Fe(II) ions mechanism. The activated Posidonia oceanica nano carbon has high adsorption capacity and adsorption rate for the removal of $\mathrm{Fe}(\mathrm{II})$ ions from aqueous solution.
\end{abstract}

Keywords: Adsorption, Fe(II) ions, Kinetics, Activated Posidonia oceanica nano carbon, Thermodynamics

\section{Introduction}

One of today's environmental challenges is the excessive use of heavy metals for industrial and domestic practices contaminates ground and surface water ${ }^{1}$, before these pollutants discharge to the environment, it is important to remove from water and wastewater ${ }^{2}$. The high $\mathrm{Fe}$ (II) concentrations also caused gastrointestinal accumulation, low hemoglobin levels and neurotoxicity. Industries such as those involved in the production of fertilizer, petrochemicals, electroplating, tanneries, metal processing, and mining industries are released $\mathrm{Fe}(\mathrm{II})$ into the environment ${ }^{3-5}$. Activated carbon has been used as an adsorbent in wastewater treatment application throughout the world, but because of its cost in efficiency it is no longer attractive to be widely used in small-scale industries. In recent years research interest into the production of adsorbents to replace the costly activated carbon has intensified ${ }^{6}$. Several studies related to wastewater treatment were carried out using low-cost materials, Posidonia oceanica is used as adsorbent because of its easily available, economically viable and biodegradable ${ }^{7}$ and also Jordanian Pottery materials was chosen as adsorbent due to its low cost, its granular structure, insolubility in water, chemical stability and local availability ${ }^{8}$. 
In the present investigation the adsorption of ferrous ion on activated nano carbon prepared from Posidonia Oceanica Ash by carbonization with sulphuric acid has been achieved. The kinetic and equilibrium adsorption data obtained were utilized to characterize the sample prepared $^{9}$. The amounts and rates of adsorption of Iron using above activated nano carbon from water were then measured. Three simplified kinetic models including pseudo first order, pseudo second order equations and Elovich equations were used to describe the adsorption process.

\section{Experimental}

The Posidonia oceanica collected (Figure 1) from nearby Thiruvarur district was carbonized with con. $\mathrm{H}_{2} \mathrm{SO}_{4}$ and activated around $1100{ }^{\circ} \mathrm{C}$ in a muffle furnace for 5 hours then it was taken out, ground well to fine powder and stored in a vacuum desiccators.

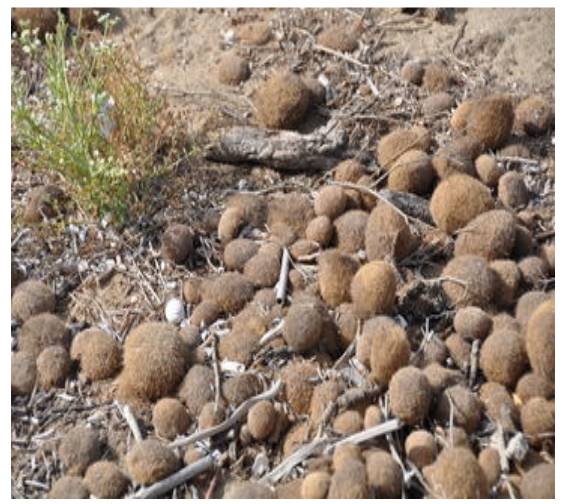

Figure 1. Photograph of Posidonia oceanica

Table 1. Physicochemical characteristics of adsorbent

\begin{tabular}{ll}
\hline \multicolumn{1}{c}{ Analysis } & Value \\
\hline $\mathrm{pH}_{\text {slurry }}$ & 5.500 \\
$\mathrm{pH}_{\text {zpc }}$ & 6.000 \\
Specific gravity & 0.195 \\
Moisture content, \% & 0.105 \\
Bulk density, $\mathrm{g} \mathrm{cm}^{-3}$ & 0.117 \\
Particle density, $\mathrm{g} \mathrm{cm}^{-3}$ & 0.285 \\
Conductivity, $\mu \mathrm{S} / \mathrm{cm}^{2}$ & 41.63 \\
$\mathrm{Surface}^{2}$ area, $\mathrm{m}^{2} / \mathrm{g}$ & 25.25 \\
$\mathrm{Na}^{+}, \mathrm{mg} \mathrm{L}^{-1}$ & 98.00 \\
$\mathrm{~K}^{+}, \mathrm{mg} \mathrm{L}^{-1}$ & 440.0 \\
\hline
\end{tabular}

\section{Adsorbent characterization}

Adsorbent characterization was performed by means of spectroscopic and quantitative analysis (Table 1). The surface area of the adsorbent was determined by quanta chrome surface area analyzer. The $\mathrm{pH}$ of aqueous slurry was determined by soaking $1 \mathrm{~g}$ of biomass in $50 \mathrm{~mL}$ distilled water, stirred for $24 \mathrm{~h}$ and filtered and the final $\mathrm{pH}$ was measured ${ }^{8}$. The physicochemical characteristics of the adsorbent were determined using standard procedures ${ }^{9}$. The concentrations of sodium and potassium were determined by Flame Photometer (Model No. Systronics126). The equilibrium $\mathrm{Cr}(\mathrm{VI})$ concentration was determined by using 1,5diphenylcarbazide as the complexing agent and a UV-Vis Spectrophotometer (Systronics, Vis double beam Spectro 1203) at a $\lambda_{\max }$ of $540 \mathrm{~nm}$. For stirring purpose magnetic stirrer was used. The $\mathrm{pH}$ of zero-point charge or $\mathrm{pH}_{\mathrm{ZPC}}$ was determined based on the previous method ${ }^{10}$. The Fourier transform infrared (FTIR) spectra of the adsorbent was recorded with Fourier transform infrared spectrophotometer in the range of $400-4000 \mathrm{~cm}^{-1}$.

\section{Batch adsorption studies}

The effect of various parameters on the removal of Fe(II) onto activated Posidonia oceanica nano carbon was studied. All chemicals used were in high level purity of the commercially available AR grade. A stock solution of the adsorbate containing $7.0210 \mathrm{mg} / \mathrm{L}$ of $\mathrm{Fe}(\mathrm{II})$ was prepared by dissolving the calculated quantity of ammonium ferrous sulphate decahydrate in deionized water. The stock solution was diluted to the required initial concentration (range 10 to 50 $\mathrm{mg} / \mathrm{L}$ ). In each adsorption experiment, $50 \mathrm{~mL}$ of $\mathrm{Fe}(\mathrm{II})$ ion solution with a known concentration was added $25 \mathrm{mg}$ of activated Posidonia oceanica nano carbon in a $250 \mathrm{~mL}$ stopper glass flask at $30,40,50$ and $60{ }^{\circ} \mathrm{C}$ and the mixture was stirred on a mechanical shaker of 60 minutes. 
The samples were withdrawn at the appropriate time intervals and the adsorbent was separated by centrifugation at $1000 \mathrm{rpm}$ for 10 minutes. The supernatant was analyzed for the residual $\mathrm{Fe}$ (II) concentration and was measured before and after treatment with an atomic absorption spectrophotometer (Perkin Elmer 2380). The effect of $\mathrm{pH}$ on the rate of adsorption was investigated using Fe(II) concentration of $50 \mathrm{mg} / \mathrm{L}$ for constant activated Posidonia oceanica nano carbon. The $\mathrm{pH}$ values were adjusted with $1 \mathrm{~N} \mathrm{HCl}$ and in $1 \mathrm{~N} \mathrm{NaOH}$ solution. The adsorption of process was carried out at different temperature $\left(30,40,50\right.$ and $\left.60{ }^{\circ} \mathrm{C}\right)$. This was helped to estimate the impact of changes of thermodynamic parameters caused by the temperature effect. The amount of adsorption at time $\mathrm{t}, \mathrm{q}_{\mathrm{t}}(\mathrm{mg} / \mathrm{g})$, can be determined using the following formula;

$$
\mathrm{q}_{\mathrm{t}}=\left(\mathrm{C}_{0}-\mathrm{C}_{\mathrm{t}}\right) \mathrm{V} / \mathrm{W}
$$

Where, $\mathrm{C}_{\mathrm{t}}$ is the $\mathrm{Fe}(\mathrm{II})$ ions liquid phase concentration(mg/L), at any time, $\mathrm{C}_{0}$ is the initial concentration of $\mathrm{Fe}(\mathrm{II})$ ions in solution $(\mathrm{mg} / \mathrm{L}), \mathrm{V}$ is the volume of solution (L), W is the mass of adsorbent $(\mathrm{g})$. The amount of adsorption at equilibrium $\mathrm{q}_{\mathrm{e}}(\mathrm{mg} / \mathrm{g})$ was computed using the following equation

$$
\mathrm{q}_{\mathrm{e}}=\left(\mathrm{C}_{0}-\mathrm{C}_{\mathrm{e}}\right) \mathrm{V} /(\mathrm{W})
$$

Where, $\mathrm{C}_{0}$ and $\mathrm{C}_{\mathrm{e}}$ are the liquid phase concentration of $\mathrm{Fe}(\mathrm{II})$ ions $(\mathrm{mg} / \mathrm{L})$ initially and at equilibrium. The removal percentage of $\mathrm{Fe}(\mathrm{II})$ ions can be calculated as:

Removal $\%$ of $\mathrm{Fe}(\mathrm{II})=\left(\mathrm{C}_{0}-\mathrm{C}_{\mathrm{e}}\right) / \mathrm{C}_{0} \times 100$

Where, $\mathrm{C}_{0}$ is the initial concentration of the $\mathrm{Fe}(\mathrm{II})$ ions in solution $(\mathrm{mg} / \mathrm{L})$ and $\mathrm{Ce}$ is the equilibrium concentration of $\mathrm{Fe}(\mathrm{II})$ ions in solution $(\mathrm{mg} / \mathrm{L})$.

\section{Results and Discussion}

\section{Effect of contact time on $\mathrm{Fe}(\mathrm{II})$ ions adsorption}

In batch adsorption process contact time is one of the potent factors. In the resultant process all of the parameters except contact time, temperature $\left(30,40,50\right.$ and $\left.60{ }^{\circ} \mathrm{C}\right)$, adsorbent dose and agitation speed $(120 \mathrm{rpm})$, were kept constant. The maximum removal of Fe(II) by activated Posidonia oceanica nano carbon required contact time of 60 minutes, it is shown in Figure 2, It was revealed that the removal of Fe(II) increase with increase in contact time and the optimal removal efficiency was reached within $45 \mathrm{~min}$. There is the maximum adsorption occurs at 45 minutes after which the adsorption phase reaches an equilibrium. At this point maximum amount of $\mathrm{Fe}$ (II) adsorbed under the particular conditions. Figure 2 indicates that, the time variation curve is single, smooth and continuous and it shows the formation of monolayer coverage on the outer interface of the adsorbent ${ }^{11}$.

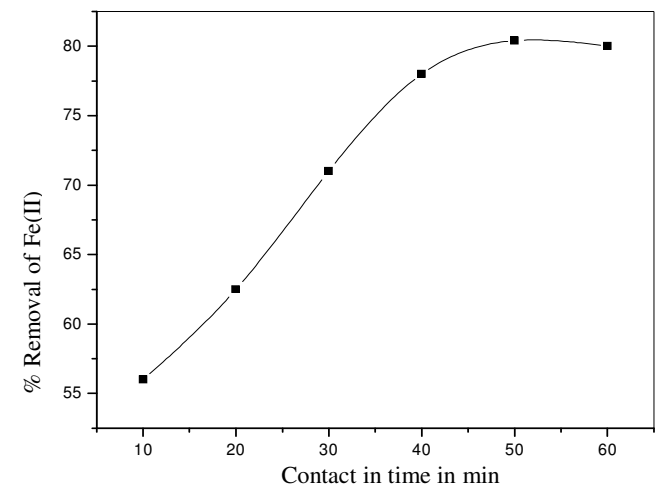

Figure 2. Effect of contact time on the removal of $\mathrm{Fe}(\mathrm{II})$ ion $[\mathrm{Fe}(\mathrm{II})]=20 \mathrm{mg} / \mathrm{L} ;$ Absorbent dose $=25 \mathrm{mg} / 50 \mathrm{~mL} ; \mathrm{Temp}=30^{\circ} \mathrm{C}$ 


\section{Effect of initial Fe(II) concentration}

To study the effect of initial Fe(II) ions on the adsorption level by varying concentration (10, 20, 30, 40 and $50 \mathrm{mg} / \mathrm{L})$ under the constant temperature $\left(30,40,50\right.$ and $\left.60{ }^{\circ} \mathrm{C}\right), \mathrm{pH} 6.5$ agitation speed $(120 \mathrm{rpm})$ and $0.025 \mathrm{~g}$ of adsorbent dose. The removal efficiency by the effect of initial $\mathrm{Fe}(\mathrm{II})$ ions concentration was obtained from the experimental results were presented in Table 2. It shows that the increasing initial Fe(II) concentration results decrease of the removal efficiency of $\mathrm{Fe}$ (II). In case of low $\mathrm{Fe}$ (II) ion concentrations the ratio of the initial number of moles of Fe(II) ions to available surface area of adsorbent is large and subsequently the fractional adsorption becomes independent of initial concentration ${ }^{10}$. However at higher concentrations of $\mathrm{Fe}$ (II) ions the available sites of adsorption becomes fewer and hence the percentage of $\mathrm{Fe}(\mathrm{II})$ ions which depends upon initial concentration.

Table 2. Equilibrium parameters for the adsorption of Fe(II) ion onto PONC

\begin{tabular}{ccccccccccccc}
\hline \multirow{2}{*}{$\mathrm{M}_{0}$} & \multicolumn{4}{c}{$\mathrm{C}_{\mathrm{e}}, \mathrm{Mg} / \mathrm{L}$} & \multicolumn{4}{c}{$\mathrm{Q}_{\mathrm{e}}, \mathrm{Mg} / \mathrm{L}$} & \multicolumn{4}{c}{ Removal \% } \\
\cline { 2 - 12 } & $30{ }^{\circ} \mathrm{C}$ & $40{ }^{\circ} \mathrm{C}$ & $50{ }^{\circ} \mathrm{C}$ & $60{ }^{\circ} \mathrm{C}$ & $30^{\circ} \mathrm{C}$ & $40{ }^{\circ} \mathrm{C}$ & $50{ }^{\circ} \mathrm{C}$ & $60{ }^{\circ} \mathrm{C}$ & $30{ }^{\circ} \mathrm{C}$ & $40{ }^{\circ} \mathrm{C}$ & $50{ }^{\circ} \mathrm{C}$ & $60{ }^{\circ} \mathrm{C}$ \\
\hline 10 & 2.507 & 2.007 & 1.757 & 1.732 & 14.99 & 15.99 & 16.49 & 16.54 & 74.93 & 79.93 & 82.43 & 82.68 \\
20 & 4.007 & 3.758 & 3.517 & 3.007 & 31.99 & 32.48 & 32.97 & 33.99 & 79.97 & 81.21 & 82.41 & 84.96 \\
30 & 7.277 & 6.708 & 6.007 & 5.658 & 45.45 & 46.58 & 47.99 & 48.68 & 75.74 & 77.64 & 79.98 & 81.14 \\
40 & 10.03 & 9.278 & 8.865 & 8.394 & 59.94 & 61.44 & 62.27 & 63.21 & 74.93 & 76.81 & 77.84 & 79.02 \\
50 & 14.26 & 13.81 & 13.53 & 12.80 & 71.49 & 72.39 & 72.94 & 74.40 & 71.49 & 72.39 & 72.94 & 74.40 \\
\hline
\end{tabular}

Effect of adsorbent dosage

The effect of varying adsorbent doses was investigated by employing 25, 50, 75, 100 and $125 \mathrm{mg}$. They were agitated with $50 \mathrm{~mL}$ of Fe(II) ions solution. The data are tabulated in Table 2. The adsorbent dosages have impact on the adsorption of Fe(II) ions by PONC are represented in Figure 3, It is revealed that the increased adsorbent doses with increase the $\mathrm{Fe}(\mathrm{II})$ ions removal. This is because the contact surface areas of adsorbent have increased. It would be more probable for Fe(II) ions on to be adsorbed on adsorption sites and the adsorption efficiency increased. Hence the entire studies were carried out with the adsorbent dosage of $25 \mathrm{mg} 50 \mathrm{~mL}$ of adsorbate solution.

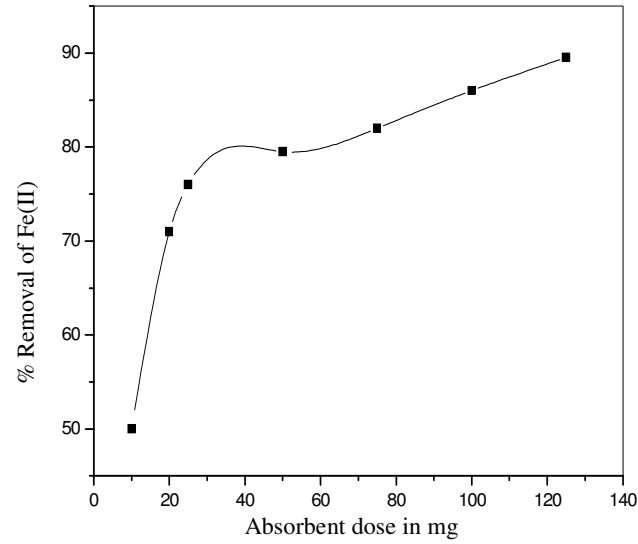

Figure 3. Effect of absorbent dose on the removal of $\mathrm{Fe}(\mathrm{II})$ ion $[\mathrm{Fe}(\mathrm{II})]=20 \mathrm{mg} / \mathrm{L} ;$ Contact time $=50 \mathrm{~min}$; Absorbent dose $=25 \mathrm{mg} / 50 \mathrm{~mL} ; \mathrm{Temp}=30^{\circ} \mathrm{C}$

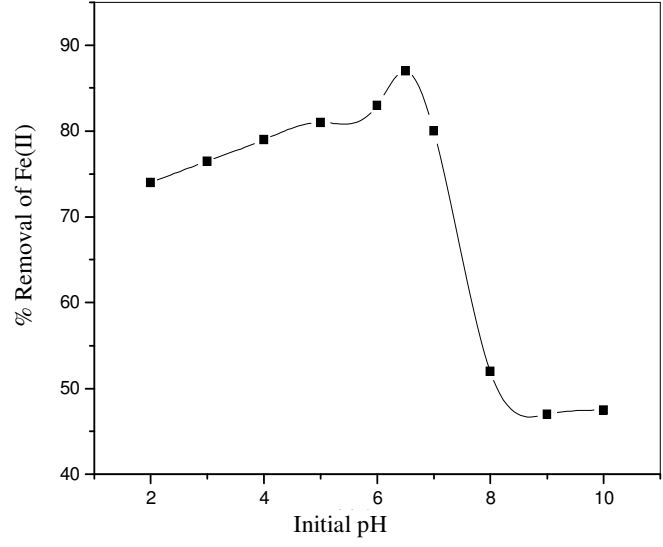

Figure 4. Effect of initial $\mathrm{pH}$ on the removal of $\mathrm{Fe}(\mathrm{II})$ ion

$[\mathrm{Fe}(\mathrm{II})]=20 \quad \mathrm{mg} / \mathrm{L} ; \quad$ Contact $\quad$ time $=50 \mathrm{~min}$; Absorbent dose $=25 \mathrm{mg} / 50 \mathrm{~mL}$; Temp $=30^{\circ} \mathrm{C}$ 


\section{Effect of solution $\mathrm{pH}$}

The solution $\mathrm{pH}$ is one of the most important factors that control the adsorption of Fe(II) ions on the sorbent material. The adsorption capacity may be attributed to the chemical form of heavy $\mathrm{Fe}(\mathrm{II})$ ion in the solution at specific $\mathrm{pH}$ (i.e.Pure ionic metal form or metal hydroxyl form). In addition, due to different functional groups on the adsorbent surface, which become active sites for the $\mathrm{Fe}(\mathrm{II})$ binding at a specific $\mathrm{pH}$ the effect of adsorption can vary substantially. Therefore, an increase in $\mathrm{pH}$ may cause an increase or decrease in the adsorption, resulting different optimum $\mathrm{pH}$ values dependent on the type of adsorbent. To examine the effect of $\mathrm{pH}$ on the \% removal of $\mathrm{Fe}(\mathrm{II})$ ions, the solution $\mathrm{pH}$ were varied from 2.0 to 10.0 by adding acid and base to the stock solution This increases may be due to the presence of negative charge on the surface of the adsorbent that may be responds for the $\mathrm{Fe}$ (II) binding. However, as the $\mathrm{pH}$ is lowered, the hydrogen ions compete with $\mathrm{Fe}(\mathrm{II})$ ions for the adsorption sites in the adsorbent, the overall surface charge on the particles become positive and hinds the binding of positively charged $\mathrm{Fe}(\mathrm{II})$ ions. On other hand, decrease in the adsorption under $\mathrm{pH}$ $>6.5$ may be due to occupation of the adsorption sites by $\mathrm{OH}^{-}$ions which retard the approach of such ions further toward the adsorbent surface. From the experimental results, the optimum $\mathrm{pH}$ range for the adsorption of the $\mathrm{Fe}$ ( III) ions is 2.0 to 6.5 shown in Figure 4.

\section{Adsorption isotherms}

Adsorption isotherm ${ }^{4-8}$ describes the relation between the amount or concentration of adsorbate that accumulates on the adsorbent and the equilibrium concentration of the dissolved adsorbate. Equilibrium studies were carried out by agitating a series of beakers containing $50 \mathrm{~mL}$ of $\mathrm{Fe}(\mathrm{II})$ ion solutions of initial concentration $20 \mathrm{mg} / \mathrm{L}$ with $0.025 \mathrm{~g}$ of activated nano carbon at $30{ }^{\circ} \mathrm{C}$ with a constant agitation. Agitation was provided for $1.0 \mathrm{~h}$, which is more than sufficient time to reach equilibrium.

\section{Freundlich adsorption isotherm}

The Freundlich adsorption isotherm is based on the equilibrium sorption on heterogeneous surfaces. This isotherm is derived from the assumption that the adsorption sites are distributed exponentially with respect to heat of adsorption ${ }^{12,18}$. The adsorption isotherm is expressed by the following equation

$$
\mathrm{q}_{\mathrm{e}}=\mathrm{K}_{\mathrm{F}} \mathrm{C}_{\mathrm{e}}{ }^{1 / \mathrm{nF}}
$$

Which, can be linearized as

$$
\ln \mathrm{q}_{\mathrm{e}}=\ln \mathrm{K}_{\mathrm{F}}+\frac{1}{\mathrm{n}_{\mathrm{F}}} \ln \mathrm{C}_{\mathrm{e}} .
$$

Where, $\mathrm{q}_{\mathrm{e}}$ is the amount of $\mathrm{Fe}(\mathrm{II})$ adsorbed at equilibrium $(\mathrm{mg} / \mathrm{g})$ and $\mathrm{C}_{\mathrm{e}}$ is the concentration of $\mathrm{Fe}(\mathrm{II})$ in the aqueous phase at equilibrium $(\mathrm{ppm}) . \mathrm{K}_{\mathrm{F}}(\mathrm{L} / \mathrm{g})$ and $1 / \mathrm{n}_{\mathrm{F}}$ are the Freundlich constants related to adsorption capacity and sorption intensity, respectively.

The Freundlich constants $\mathrm{K}_{\mathrm{F}}$ and $1 / \mathrm{n}_{\mathrm{F}}$ were calculated from the slope and intercept of the $\operatorname{lnq}_{\mathrm{e}} v s . \operatorname{lnC}_{\mathrm{e}}$ plot and the model Freundlich parameters are shown in Table 3. The magnitude of $\mathrm{K}_{\mathrm{F}}$ showed that PONC had a high capacity for $\mathrm{Fe}(\mathrm{II})$ adsorption from the aqueous solutions studied. The Freundlich exponent, $\mathrm{n}_{\mathrm{F}}$, should have values in the range of 1 and 10 (i.e., $1 / \mathrm{n}_{\mathrm{F}}<1$ ) to be considered as favourable adsorption ${ }^{9}$. A $1 / \mathrm{n}_{\mathrm{F}}$ value of less than 1 indicated that $\mathrm{Fe}(\mathrm{II})$ is favorably adsorbed by PONC. The Freundlich isotherm did not show a good fit to the experimental data as indicated by SSE and Chi-square statistics. 


\section{Langmuir adsorption isotherm}

The Langmuir adsorption isotherm is based on the assumption that all sorption sites possess equal affinity to the adsorbate. The Langmuir isotherm ${ }^{10}$ in a linear form can be represented as:

$$
\frac{C_{e}}{q_{e}}=\frac{1}{q_{m} K_{L}}+\frac{C_{e}}{q_{m}}
$$

Where $\mathrm{q}_{\mathrm{e}}$ is the amount of $\mathrm{Fe}$ (II) adsorbed at equilibrium $(\mathrm{mg} / \mathrm{g}), \mathrm{C}_{\mathrm{e}}$ is the concentration of $\mathrm{Fe}(\mathrm{II})$ in the aqueous phase at equilibrium (ppm), $\mathrm{q}_{\mathrm{m}}$ is the maximum $\mathrm{Fe}(\mathrm{II})$ uptake $(\mathrm{mg} / \mathrm{g})$, and $\mathrm{K}_{\mathrm{L}}$ is the Langmuir constant related to adsorption capacity and the energy of adsorption $(\mathrm{g} / \mathrm{mg})$.

A linear plot of $\mathrm{C}_{\mathrm{e}} / \mathrm{q}_{\mathrm{e}} v s . \mathrm{C}_{\mathrm{e}}$ was employed to determine the value of $\mathrm{q}_{\mathrm{m}}$ and $\mathrm{K}_{\mathrm{L}}$ and the data so obtained were also presented in Table 3 . The model predicted a maximum value that could not be reached in the experiments. The value of $\mathrm{K}_{\mathrm{L}}$ decreases with an increase in the temperature ${ }^{13,19}$. A high $\mathrm{K}_{\mathrm{L}}$ value indicates a high adsorption affinity. Weber ${ }^{22}$ expressed the Langmuir isotherm in term of dimensionless constant separation factor or equilibrium parameter $\left(\mathrm{R}_{\mathrm{L}}\right)$ defined in the following equation:

$$
\mathrm{R}_{\mathrm{L}}=\frac{1}{1+\mathrm{K}_{\mathrm{L}} \mathrm{C}_{0}}
$$

Where, $\mathrm{C}_{0}$ is the initial $\mathrm{Fe}(\mathrm{II})$ concentration (ppm).

Table 3. Isotherms parameter for the adsorption of $\mathrm{Fe}(\mathrm{II})$ ion onto PONC

\begin{tabular}{cccccc}
\hline \multirow{2}{*}{ Model } & \multirow{2}{*}{ Constant } & \multicolumn{4}{c}{ Temperature $\left({ }^{\circ} \mathrm{C}\right)$} \\
\cline { 2 - 5 } & & 30 & 40 & 50 & 60 \\
\hline \multirow{2}{*}{ Freundlich } & $\mathrm{K}$ & 1.1599 & 1.2811 & 1.3610 & 1.3683 \\
\cline { 2 - 5 } & $\mathrm{K}_{\mathrm{f}}(\mathrm{mg} / \mathrm{g})(\mathrm{L} / \mathrm{mg})^{1 / \mathrm{n}}$ & 7.9621 & 10.264 & 11.982 & 12.890 \\
\cline { 2 - 5 } Langmuir & $\mathrm{Q}_{\mathrm{m}}(\mathrm{mg} / \mathrm{g})$ & 242.54 & 168.18 & 144.36 & 145.64 \\
\cline { 2 - 5 } & $\mathrm{K}_{\mathrm{L}}(\mathrm{L} / \mathrm{mg})$ & 0.0311 & 0.0577 & 0.0800 & 0.0864 \\
\cline { 2 - 5 } Temkin & $\mathrm{b}_{\mathrm{T}}(\mathrm{J} / \mathrm{mol})$ & 31.779 & 29.429 & 28.203 & 28.737 \\
\cline { 2 - 5 } & $\mathrm{K}_{\mathrm{T}}(\mathrm{L} / \mathrm{mg})$ & 0.8376 & 0.9357 & 0.9910 & 1.0108 \\
\hline \multirow{2}{*}{ Hurkins-Jura } & $\mathrm{A}_{\mathrm{H}}\left(\mathrm{g}^{2} / \mathrm{L}\right)$ & -199.90 & -239.16 & -266.59 & -278.24 \\
\cline { 2 - 5 } & $\mathrm{B}_{\mathrm{H}}\left(\mathrm{mg}^{2} / \mathrm{L}\right)$ & -1.0592 & -1.0386 & -1.0219 & -0.9992 \\
\hline \multirow{2}{*}{ Halsay } & $\mathrm{K}_{\mathrm{Ha}}(\mathrm{mg} / \mathrm{L})$ & 11.095 & 19.752 & 29.371 & 33.047 \\
\cline { 2 - 5 } Radlich- & $\mathrm{n}_{\mathrm{Ha}}$ & 1.1599 & 1.2811 & 1.3610 & 1.3683 \\
Peterson & $\mathrm{g}$ & 0.1379 & 0.2194 & 0.2653 & 0.2692 \\
\hline \multirow{2}{*}{ Dubinin- } & $\mathrm{K}_{\mathrm{R}}(\mathrm{L} / \mathrm{g})$ & 0.1256 & 0.0974 & 0.0835 & 0.0776 \\
\cline { 2 - 5 } Radushkevich & $\mathrm{q}_{\mathrm{s}}(\mathrm{mg} / \mathrm{g})$ & 66.045 & 63.182 & 62.989 & 66.749 \\
\cline { 2 - 5 } & $\mathrm{K}_{\mathrm{D}} \times 10^{-4} \mathrm{~mol}{ }^{2} \mathrm{~kJ}^{-2}$ & 1.5073 & 1.4925 & 1.4882 & 1.4976 \\
\cline { 2 - 5 } Jovanovic & $\mathrm{K}_{\mathrm{J}}(\mathrm{L} / \mathrm{g})$ & 0.1190 & 0.1175 & 0.1149 & 0.1198 \\
\cline { 2 - 5 } & $\mathrm{q}_{\mathrm{max}}(\mathrm{mg} / \mathrm{g})$ & 15.865 & 17.518 & 18.988 & 19.644 \\
\hline \multirow{2}{*}{ BET } & $\mathrm{C}_{\mathrm{BET}}(\mathrm{L} / \mathrm{mg})$ & 7.9326 & 3.6465 & 4.6859 & 6.0441 \\
& $\mathrm{qs}(\mathrm{mg} / \mathrm{g})$ & 0.1261 & 0.2742 & 0.2134 & 0.1655 \\
\hline
\end{tabular}

Four scenarios can be distinguished: The sorption isotherm is unfavorable when $R_{L}>1$, the isotherm is linear when $R_{L}=1$, The isotherm is favorable when $0<R_{L}<1$ and the isotherm is irreversible when $R_{L}=0$. The values of dimensionless separation factor $\left(R_{L}\right)$ for $\mathrm{Fe}(\mathrm{II})$ removal were calculated at different concentrations and temperatures. As shown in Table 4, at all concentrations and temperatures tested the values of $\mathrm{R}_{\mathrm{L}}$ for $\mathrm{Fe}(\mathrm{II})$ adsorptions on the PONC were less than 1 and greater than zero, indicating favorable adsorption. 
The Langmuir isotherm showed a better fit to the adsorption data than the Freundlich isotherm. The fact that the Langmuir isotherm fits the experimental data well may be due to homogeneous distribution of active sites on the PONC surface, since the Langmuir equation assumes that the adsorbent surface is energetically homogeneous.

Table 4. Dimensionless seperation factor $\left(\mathrm{R}_{\mathrm{L}}\right)$ for the adsorption of $\mathrm{Fe}(\mathrm{II})$ ion onto PONC

\begin{tabular}{ccccc}
\hline \multirow{2}{*}{$\left(\mathrm{C}_{\mathrm{i}}\right)$} & \multicolumn{4}{c}{ Dimensionless seperation factor, $\mathrm{R}_{\mathrm{L}}$} \\
\cline { 2 - 5 } & $30{ }^{\circ} \mathrm{C}$ & $40{ }^{\circ} \mathrm{C}$ & $50{ }^{\circ} \mathrm{C}$ & $60{ }^{\circ} \mathrm{C}$ \\
\hline 10 & 0.5624 & 0.4095 & 0.3334 & 0.3165 \\
20 & 0.3912 & 0.2575 & 0.2000 & 0.1880 \\
30 & 0.2999 & 0.1878 & 0.1429 & 0.1337 \\
40 & 0.2432 & 0.1478 & 0.1111 & 0.1037 \\
50 & 0.2045 & 0.1218 & 0.0909 & 0.0847 \\
\hline
\end{tabular}

\section{Temkin adsorption isotherm}

The Temkin adsorption isotherm assumes that the heat of adsorption decreases linearly with the sorption coverage due to adsorbent-adsorbate interactions ${ }^{14}$. The Temkin isotherm equation is given as:

$$
\mathrm{q}_{\mathrm{e}}=\frac{\mathrm{RT}}{\mathrm{bT}} \ln \left(\mathrm{K}_{\mathrm{T}} \mathrm{C}_{\mathrm{e}}\right)
$$

Which, can be represented in the following linear form

$$
\mathrm{q}_{\mathrm{e}}=\frac{\mathrm{RT}}{\mathrm{b}} \ln \mathrm{K}_{\mathrm{T}}+\frac{\mathrm{RT}}{\mathrm{b}} \ln \mathrm{C}_{\mathrm{e}}
$$

Where, $\mathrm{K}_{\mathrm{T}}(\mathrm{L} / \mathrm{g})$ is the Temkin isotherm constant, $\mathrm{b}_{\mathrm{T}}(\mathrm{J} / \mathrm{mol})$ is a constant related to heat of sorption, $R$ is the ideal gas constant $(8.314 \mathrm{~J} / \mathrm{mol} \mathrm{K})$, and $\mathrm{T}$ is absolute temperature $(\mathrm{K})$. A plot of $\mathrm{q}_{\mathrm{e}}$ versus $\operatorname{lnC}_{\mathrm{e}}$ enables the determination of isotherm constants $\mathrm{K}_{\mathrm{T}}$ and $\mathrm{b}_{\mathrm{T}}$ from the slope and intercept. The model parameters are listed in Table 3. The Temkin isotherm appears to provide a good fit to the Fe(II) adsorption data.

The adsorption energy in the Temkin model, $\mathrm{b}_{\mathrm{T}}$, is positive for Fe(II) adsorption from the aqueous solution, which indicates that the adsorption is endothermic. The experimental equilibrium curve is close to that predicted by Temkin model. Consequently, the adsorption isotherm of Fe(II) on PONC can be described reasonably well by the Temkin isotherm.

\section{Hurkins-Jura adsorption isotherm}

The Hurkins-Jura ${ }^{12}$ adsorption isotherm can be expressed as:

$$
q_{e}=\sqrt{\frac{A_{H}}{B_{H}+\log C_{e}}}
$$

This can rearranged as follows:

$$
\frac{1}{\mathrm{q}_{\mathrm{e}}^{2}}=\frac{\mathrm{B}_{\mathrm{H}}}{\mathrm{A}_{\mathrm{H}}}-\frac{1}{\mathrm{~A}_{\mathrm{H}}} \log \mathrm{C}_{\mathrm{e}}
$$

Where, $A_{H}\left(g^{2} / L\right)$ and $B_{H}\left(\mathrm{mg}^{2} / \mathrm{L}\right)$ are two parameters characterizing the sorption equilibrium. The isotherm equation accounts for multilayer adsorption and can be explained by the existence of a heterogeneous pore distribution. The Harkins-Jura isotherm parameters are obtained from the plots of of $1 / \mathrm{q}_{\mathrm{e}}^{2}$ versus $\log \mathrm{C}_{\mathrm{e}}$ enables the determination of model parameters $\mathrm{A}_{\mathrm{H}}$ and $\mathrm{B}_{\mathrm{H}}$ from the slope and intercept ${ }^{15}$. 


\section{Halsay adsorption isotherm}

The Halsay ${ }^{13}$ adsorption isotherm can be given as

$$
\mathrm{q}_{\mathrm{e}}=\exp \left(\frac{\ln \mathrm{K}_{\mathrm{Ha}}-\operatorname{lnC}_{\mathrm{e}}}{\mathrm{n}_{\mathrm{Ha}}}\right)
$$

and a linear form of the isotherm can be expressed as follows:

$$
\operatorname{lnq} \mathrm{e}_{\mathrm{e}}=\frac{\ln \mathrm{K}_{\mathrm{Ha}}}{\mathrm{n}_{\mathrm{Ha}}}-\frac{\ln \mathrm{C}_{\mathrm{e}}}{\mathrm{n}_{\mathrm{Ha}}}
$$

Where, $\mathrm{K}_{\mathrm{Ha}}(\mathrm{mg} / \mathrm{L})$ and $\mathrm{n}_{\mathrm{Ha}}$ are the Halsay isotherm constants.

A plot of $\operatorname{lnq}_{\mathrm{e}} v s . \operatorname{lnC}_{\mathrm{e}}$ enables the determination of $\mathrm{n}_{\mathrm{Ha}}$ and $\mathrm{K}_{\mathrm{Ha}}$ from the slope and intercept. This equation is suitable for multilayer adsorption and the fitting of the experimental data to this equation attest to the heteroporous nature of adsorbent. The experimental data and the model predictions based on the non-linear form of the Halsay models. The model parameters are listed in Table 3. This result also shows that the adsorption of $\mathrm{Fe}(\mathrm{II})$ on PONC was not based on significant multilayer adsorption. The Halsay model is also not suitable to describe the adsorption of Fe(II) on PONC, because this model also assumes a multilayer behavior for the adsorption of adsorbate onto adsorbent.

\section{Redlich-Peterson adsorption isotherm}

The Redlich-Peterson ${ }^{16}$ adsorption isotherm contains three parameters and incorporates the features of Langmuir and Freundlich isotherms into a single equation. The general isotherm equation can be described as follows:

$$
\mathrm{q}_{\mathrm{e}}=\frac{\mathrm{K}_{\mathrm{R}} \mathrm{C}_{\mathrm{e}}}{1+\mathrm{a}_{\mathrm{R}} \mathrm{C}_{\mathrm{e}}^{\mathrm{g}}} \text {. }
$$

The linear form of the isotherm can be expressed as follows:

$$
\ln \frac{\mathrm{C}_{\mathrm{e}}}{\mathrm{q}_{\mathrm{e}}}=\mathrm{gln}_{\mathrm{e}}-\ln \mathrm{K}_{\mathrm{R}} .
$$

Where, $K_{R}(\mathrm{~L} / \mathrm{g})$ and $\mathrm{a}_{\mathrm{R}}(\mathrm{L} / \mathrm{mg})$ are the Radlich-Peterson isotherm constants and $\mathrm{g}$ is the exponent between 0 and 1 . There are two limiting cases: Langmuir form for $g=1$ and Henry's law for $\mathrm{g}=0$.

A plot of $\ln \mathrm{C}_{\mathrm{e}} / \mathrm{q}_{\mathrm{e}}$ versus $\ln \mathrm{C}_{\mathrm{e}}$ enables the determination of isotherm constants $\mathrm{g}$ and $\mathrm{K}_{\mathrm{R}}$ from the slope and intercept. The values of $\mathrm{K}_{\mathrm{R}}$, presented in Table 3, indicate that the adsorption capacity of the PONC decreased with an increase temperature. Furthermore, the value of $\mathrm{g}$ lies between 0 and 1 , indicating favorable adsorption.

\section{Dubinin-Radushkevich adsorption isotherm}

The Dubinin-Radushkevich ${ }^{15}$ adsorption isotherm is another isotherm equation ${ }^{17}$. It is assumed that the characteristic of the sorption curve is related to the porosity of the adsorbent. The linear form of the isotherm can be expressed as follows:

$$
\operatorname{lnq}_{\mathrm{e}}=\ln _{\mathrm{D}}-\mathrm{B}_{\mathrm{D}}\left[\operatorname{RT} \ln \left(1+\frac{1}{\mathrm{C}_{\mathrm{e}}}\right)\right]^{2}
$$

Where, $Q_{D}$ is the maximum sorption capacity $(\mathrm{mol} / \mathrm{g})$, and $\mathrm{B}_{\mathrm{D}}$ is the DubininRadushkevich constant $\left(\mathrm{mol}^{2} / \mathrm{kJ}^{2}\right)$. A plot of $\operatorname{lnq}_{\mathrm{e}} v s$. $\mathrm{R}_{\mathrm{T}} \ln \left(1+1 / \mathrm{C}_{\mathrm{e}}\right)$ enables the determination of isotherm constants $\mathrm{B}_{\mathrm{D}}$ and $\mathrm{Q}_{\mathrm{D}}$ from the slope and intercept. 


\section{Jovanovich adsorption isotherm}

The model of an adsorption surface considered by Jovanovic ${ }^{16}$ is essentially the same as that considered by Langmuir. The Jovanovic model leads to the following relationship ${ }^{18}$ :

$$
\mathrm{q}_{\mathrm{e}}=\mathrm{q}_{\max }\left(1-\mathrm{e}^{\mathrm{K}_{\mathrm{J}} \mathrm{C}_{\mathrm{e}}}\right)
$$

The linear form of the isotherm can be expressed as follows:

$$
\ln \mathrm{q}_{\mathrm{e}}=\ln \mathrm{q}_{\max }-\mathrm{K}_{\mathrm{J}} \mathrm{C}_{\mathrm{e}} \text {. }
$$

Where, $\mathrm{K}_{\mathrm{J}}(\mathrm{L} / \mathrm{g})$ is a parameter. $\mathrm{q}_{\max }(\mathrm{mg} / \mathrm{g})$ is the maximum $\mathrm{Fe}(\mathrm{II})$ uptake.

The $\mathrm{q}_{\max }$ is obtained from a plot of $\ln \mathrm{q}_{\mathrm{e}}$ and $\mathrm{C}_{\mathrm{e}}$, Their related parameters are listed in Table 3. By comparing the values of the error functions, it was found the Langmuir and Temkin models are best to fit the Fe(II) adsorption on the PONC. Both models show a high degree of correlation. This is clearly confirming the good fit of Langmuir and Temkin models with the experimental data for removal of Fe(II) from the solution.

\section{The Brunauer-Emmett-Teller (BET) isotherm model}

Brunauer-Emmett-Teller (BET) ${ }^{19}$ isotherm is a theoretical equation, most widely applied in the gas-solid equilibrium systems. It was developed to derive multilayer adsorption systems with relative concentration ranges from 10 to $50 \mathrm{mg} / \mathrm{L}$ corresponding to a monolayer coverage lying between 20 and $30 \mathrm{mg} / \mathrm{L}$. Its extinction model related to liquid-solid interface is exhibited as:

$$
\mathrm{q}_{\mathrm{e}}=\frac{\mathrm{q}_{\mathrm{s}} \mathrm{C}_{\mathrm{BET}} \mathrm{C}_{\mathrm{e}}}{\left(\mathrm{C}_{\mathrm{s}}-\mathrm{C}_{\mathrm{e}}\right)\left[1+\left(\mathrm{C}_{\mathrm{BET}}-1\right)\left(\mathrm{C}_{\mathrm{e}} / \mathrm{C}_{\mathrm{s}}\right)\right]}
$$

Where, $\mathrm{C}_{\mathrm{BET}}$, Cs, qs and qe are the BET adsorption isotherm $(\mathrm{L} / \mathrm{mg})$, adsorbate monolayer saturation concentration $(\mathrm{mg} / \mathrm{L})$, theoretical isotherm saturation capacity $(\mathrm{mg} / \mathrm{g}$ ) and equilibrium adsorption capacity $(\mathrm{mg} / \mathrm{g})$, respectively. As $\mathrm{C}_{\mathrm{BET}}$ and $\mathrm{C}_{\mathrm{BET}}\left(\mathrm{C}_{\mathrm{e}} / \mathrm{C}_{\mathrm{s}}\right)$ is much greater than 1 , In the linear form as used is represented as

$$
\frac{\mathrm{C}_{\mathrm{e}}}{\mathrm{q}\left(\mathrm{C}_{\mathrm{s}}-\mathrm{C}_{\mathrm{e}}\right)}=\frac{1}{\mathrm{q}_{\mathrm{s}} \mathrm{C}_{\mathrm{BET}}}+\left(\frac{\mathrm{C}_{\mathrm{BET}^{-1}}}{\mathrm{q}_{\mathrm{s}} \mathrm{C}_{\mathrm{BET}}}\right)\left(\frac{\mathrm{C}_{\mathrm{e}}}{\mathrm{C}_{\mathrm{s}}}\right) \text {. }
$$

Where, $\mathrm{C}_{\mathrm{e}}$ is equilibrium Concentration $(\mathrm{mg} / \mathrm{L}), \mathrm{C}_{\mathrm{s}}$ is adsorbate monolayer saturation concentration $(\mathrm{mg} / \mathrm{l})$ and $\mathrm{C}_{\mathrm{BET}}$ is BET adsorption relating to the energy of surface interaction $(1 / \mathrm{mg})$ the BET model.

\section{Kinetic parameters}

The rate and mechanism of the adsorption process can be elucidated based on kinetic studies. Fe(II)adsorption on solid surface may be explained by two distinct mechanisms: (1) An initial rapid binding of $\mathrm{Fe}(\mathrm{II})$ molecules on the adsorbent surface; (2) relatively slow intra-particle diffusion. To analyze the adsorption kinetics of the $\mathrm{Fe}(\mathrm{II})$, the pseudo-firstorder, the pseudo-second-order, and intra-particle diffusion models were applied ${ }^{18}$. Each of these models and their linear modes of them equations presented in below.

$\begin{array}{lcc}\text { Model } & \text { Nonlinear Form } & \text { Linear Form } \\ \text { Pseudo-first-order } & \mathrm{dq}_{\mathrm{t}} / \mathrm{d}_{\mathrm{t}}=\mathrm{k}_{1}\left(\mathrm{q}_{\mathrm{e}}-\mathrm{q}_{\mathrm{t}}\right) & \ln \left(\mathrm{q}_{\mathrm{e}}-\mathrm{q}_{\mathrm{t}}\right)=\ln \mathrm{q}_{\mathrm{e}}-\mathrm{k}_{1} \mathrm{t} \\ \text { Pseudo-second-order } & \mathrm{dq}_{\mathrm{t}} / \mathrm{d}_{\mathrm{t}}=\mathrm{k}_{2}\left(\mathrm{q}_{\mathrm{e}}-\mathrm{q}_{\mathrm{t}}\right)^{2} & \mathrm{t} / \mathrm{q}_{\mathrm{t}}=1 / \mathrm{k}^{2} \mathrm{q}_{\mathrm{e}}{ }^{2}+\left(1 / \mathrm{q}_{\mathrm{e}}\right) \mathrm{t}\end{array}$


Where, $\mathrm{q}_{\mathrm{e}}$ and $\mathrm{q}_{\mathrm{t}}$ refer to the amount of $\mathrm{Fe}(\mathrm{II})$ adsorbed $(\mathrm{mg} / \mathrm{g})$ at equilibrium and at any time, $\mathrm{t}(\mathrm{min})$, respectively and $\mathrm{k}_{1}(1 / \mathrm{min}), \mathrm{k}_{2}(\mathrm{~g} / \mathrm{mg} \cdot \mathrm{min})$ are the equilibrium rate constants of pseudo-first order and pseudo-second order models, respectively.

Pseudo-first order model is a simple kinetic model, which was proposed by Lagergren during 1898 and is used for estimation of the surface adsorption reaction rate. The values of $\ln \left(\mathrm{q}_{\mathrm{e}}-\mathrm{q}_{\mathrm{t}}\right)$ were linearly correlated with $\mathrm{t}$. The plot of $\ln \left(\mathrm{q}_{\mathrm{e}}-\mathrm{q}_{\mathrm{t}}\right) v s$. $\mathrm{t}$ should give a linear relationship from which the values of $\mathrm{k}_{1}$ were determined from the slope of the plot. In many cases, the first-order equation of Lagergren does not fit well with the entire range of contact time and is generally applicable over the initial stage of the adsorption processes.

In the pseudo-second order model, the slope and intercept of the t/qt $v s$. $t$ plot were used to calculate the second-order rate constant, $\mathrm{k}_{2}$. The values of equilibrium rate constant $\left(\mathrm{k}_{2}\right)$ are presented in Table 5. According to Table 5, the value of $\gamma(0.999)$ related to the pseudosecond order model revealed that $\mathrm{Fe}(\mathrm{II})$ adsorption followed this model, nevertheless, pseudo-first order and pseudo-second order kinetic models cannot identify the mechanism of diffusion of $\mathrm{Fe}(\mathrm{II})$ into the adsorbent pores ${ }^{20}$.

Table 5. The kinetic parameters for the adsorption of Fe(II) ion onto PONC

\begin{tabular}{|c|c|c|c|c|c|c|c|c|c|c|c|}
\hline \multirow{2}{*}{$\mathrm{C}_{0}$} & \multirow{2}{*}{ 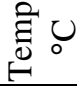 } & \multicolumn{4}{|c|}{ Pseudo second order } & \multicolumn{3}{|c|}{ Elovich model } & \multicolumn{3}{|c|}{ Intraparticle diffusion } \\
\hline & & $\mathrm{q}_{\mathrm{e}}$ & $\mathrm{k}_{2}$ & $\gamma$ & $\mathrm{h}$ & $\alpha$ & $\beta$ & $\gamma$ & $\overline{\mathrm{K}_{\mathrm{id}}}$ & $\gamma$ & $\mathrm{C}$ \\
\hline \multirow[t]{4}{*}{10} & 30 & 15.20 & 0.0158 & 0.9901 & 3.653 & 64.00 & 0.5615 & 0.9939 & 0.0181 & 0.9889 & 1.863 \\
\hline & 40 & 17.31 & 0.0096 & 0.9902 & 2.862 & 94.40 & 0.4787 & 0.9866 & 0.1456 & 0.9881 & 1.637 \\
\hline & 50 & 17.27 & 0.0163 & 0.9959 & 4.876 & 97.82 & 0.7172 & 0.9868 & 0.0905 & 0.9909 & 1.751 \\
\hline & 60 & 17.28 & 0.0174 & 0.9929 & 5.203 & 51.83 & 0.7557 & 0.9879 & 0.0853 & 0.9920 & 1.761 \\
\hline \multirow[t]{4}{*}{20} & 30 & 35.39 & 0.0034 & 0.9963 & 4.250 & 40.85 & 0.2003 & 0.9922 & 0.1791 & 0.9942 & 1.570 \\
\hline & 40 & 35.63 & 0.0038 & 0.9909 & 4.807 & 60.29 & 0.2097 & 0.9877 & 0.1666 & 0.9909 & 1.602 \\
\hline & 50 & 35.98 & 0.0043 & 0.9943 & 5.597 & 96.13 & 0.2200 & 0.9872 & 0.1541 & 0.9935 & 1.636 \\
\hline & 60 & 36.47 & 0.0049 & 0.9904 & 6.489 & 222.4 & 0.2427 & 0.9889 & 0.1344 & 0.9952 & 1.682 \\
\hline \multirow[t]{4}{*}{30} & 30 & 48.48 & 0.0037 & 0.9912 & 8.685 & 557.2 & 0.1997 & 0.9926 & 0.1213 & 0.9892 & 1.651 \\
\hline & 40 & 50.21 & 0.0040 & 0.9970 & 10.165 & 461.3 & 0.1837 & 0.9867 & 0. & 0.9883 & 1.663 \\
\hline & 50 & 52.24 & 0.0034 & 0.9955 & 9.299 & 200.7 & 0.1576 & 0.9890 & 0.1458 & 0.9875 & 1.644 \\
\hline & 60 & 51.84 & 0.0050 & 0.9971 & 13.32 & 809.2 & 0.1856 & 0.9868 & 0.1200 & 0.9877 & 1.700 \\
\hline \multirow[t]{4}{*}{40} & 30 & 64.42 & 0.0037 & 0.9945 & 15.21 & 480.4 & 0.1362 & 0.9906 & 0.1335 & 0.9896 & 1.644 \\
\hline & 40 & 65.91 & 0.0034 & 0.9904 & 14.95 & 486.4 & 0.1336 & 0.9883 & 0.1334 & 0.9905 & 1.652 \\
\hline & 50 & 66.56 & 0.0037 & 0.9934 & 16.30 & 666.2 & 0.1369 & 0.9930 & 0.1278 & 0.9926 & 1.669 \\
\hline & 60 & 67.52 & 0.0037 & 0.9965 & 16.79 & 762.2 & 0.1370 & 0.9886 & 0.1256 & 0.9937 & 1.680 \\
\hline \multirow[t]{4}{*}{50} & 30 & 76.44 & 0.0022 & 0.9912 & 12.60 & 442.5 & 0.1162 & 0.9888 & 0.1342 & 0.9924 & 1.601 \\
\hline & 40 & 77.49 & 0.0021 & 0.9972 & 12.71 & 440.9 & 0.1145 & 0.9881 & 0.1345 & 0.9945 & 1.606 \\
\hline & 50 & 77.66 & 0.0023 & 0.9906 & 13.73 & 719.7 & 0.1212 & 0.9888 & 0.1252 & 0.9892 & 1.626 \\
\hline & 60 & 79.41 & 0.0021 & 0.9930 & 13.16 & 503.2 & 0.1133 & 0.9917 & 0.1322 & 0.9892 & 1.621 \\
\hline
\end{tabular}

Simple Elovich model

The simple Elovich model ${ }^{21}$ is expressed in the form,

$$
\mathrm{q}_{\mathrm{t}}=\alpha+\beta \ln \mathrm{t}
$$

Where, $\mathrm{q}_{\mathrm{t}}$ is the amount adsorbed at time $\mathrm{t}, \alpha$ and $\beta$ are the constants obtained from the experiment. A plot of $\mathrm{q}_{\mathrm{t}} v s$. Int should give a linear relationship for the applicability of the simple Elovich kinetic. The Elovich kinetics of $\mathrm{Fe}(\mathrm{II})$ on to PONC for various initial concentrations $(10,20,30,40$ and $50 \mathrm{mg} / \mathrm{L})$ of volume $50 \mathrm{~mL}$ (each), adsorbent dose $0.025 \mathrm{~g}$, temperature $30{ }^{\circ} \mathrm{C}$ and $\mathrm{pH} 6.5$. 


\section{The intra-particle diffusion model}

The Weber and Morris ${ }^{22}$ suggest the following kinetic model to identifying the mechanism involved in the adsorption process is of an intra-particle diffusion model or not. It is generally expressed as

$$
\mathrm{q}_{\mathrm{t}}=\mathrm{K}_{\mathrm{id}} \mathrm{t}^{1 / 2}+\mathrm{C}
$$

Where, $K_{i d}$ is the intra-particle rate constant $\left(\mathrm{mg} / \mathrm{g} / \mathrm{min}^{1 / 2}\right)$, $\mathrm{c}$ is the intercept, $\mathrm{q}_{\mathrm{t}}$ is the amount of $\mathrm{Fe}$ (II) ions adsorbed (mg/g), at time t. From the plot of $\mathrm{q}_{\mathrm{t}} v s . \mathrm{t}^{1 / 2}$, the intra-particle rate constant can be determined from the slope of the plot. The value of $\mathrm{C}$ gives an idea about the boundary layer thickness. The calculated intra-particle diffusion parameters present in Table 5. The $\gamma$ values indicate that, intra-particle diffusion process is the controls the sorption rate.

\section{Thermodynamic parameters}

Thermodynamic parameters such as standard free energy $\left(\Delta \mathrm{G}^{0}\right)$ standard enthalpy change $\left(\Delta \mathrm{H}^{0}\right)$ and standard entropy changes $\left(\Delta \mathrm{S}^{0}\right)$ were calculated by using equilibrium constant $\left(\mathrm{K}_{0}\right)$ change with temperature $(\mathrm{T})$. The free energy change can be determined by the following equation ${ }^{21}$.

$$
\Delta \mathrm{G}^{0}=-\mathrm{RT} \ln \mathrm{Ko}
$$

Where, $\Delta \mathrm{G}^{0}$ is the free energy change of sorption process $(\mathrm{kJ} / \mathrm{mol}), \mathrm{K}_{\mathrm{o}}$ is the equilibrium constant, $\mathrm{T}$ is the temperature in $(\mathrm{K}), \mathrm{R}$ is the universal gas constant. The free energy change may be expressed in terms of enthalpy change of sorption as a function of temperature as follows

$$
\Delta \mathrm{G}^{0}=\Delta \mathrm{H}-\mathrm{T} \Delta \mathrm{S}
$$

The adsorption coefficient $\mathrm{K}_{0}$ can be obtained by combined and rearranging Eqs. 25 and 26.

$$
\ln \mathrm{K}_{0}=\Delta \mathrm{H}^{0} / \mathrm{RT}+\Delta \mathrm{S}^{0} / \mathrm{R}
$$

Where, $\Delta \mathrm{H}^{0}$ is the standard heat changes of the sorption, $\Delta \mathrm{S}^{0}$ is the entropy change of sorption $(\mathrm{kJ} / \mathrm{mol})$. The standard enthalpy and entropy changes values are evaluated from the slope and intercept of linear plot $\operatorname{lnk}_{0}$ against $1 / \mathrm{T}$. Thermodynamic parameter values are obtained from the equation (8) for the sorption of Fe(II) ions on activated Posidonia oceanica nano carbon and the values are tabulated in Table 6 . The negative values of free energy changes confirm the spontaneous nature of sorption of Fe(II) on activated Posidonia oceanica nano carbon and the negative values of $\Delta \mathrm{H}^{0}$ confirm the sorption process of an exothermic nature. The positive $\Delta S^{0}$ values show increased randomness at solid-solution interface during the sorption of $\mathrm{Fe}(\mathrm{II})$ ions on the activated Posidonia oceanica nano carbon.

In order to support that physical adsorption is the predominant mechanism, the values of activation energy (Ea) and sticking probability $\left(\mathrm{S}^{*}\right)$ were calculated from the experimental data. They were calculated using modified Arrhenius type equation related to surface coverage $(\theta)$ as follows:

$$
\begin{gathered}
\theta=\left(1-\frac{\mathrm{C}_{\mathrm{e}}}{\mathrm{C}_{\mathrm{i}}}\right) \\
S^{*}=(1-\theta)_{e} \frac{-E_{a}}{R T}
\end{gathered}
$$

The sticking probability, $\mathrm{S}^{*}$, is a function of the adsorbate/adsorbent system under consideration but must satisfy the condition $0<\mathrm{S}^{*}<1$ and is dependent on the temperature of the system ${ }^{23}$. The values of Ea and $S^{*}$ can be calculated from slope and intercept of the plot of $\ln (1-\theta)$ versus $1 / \mathrm{T}$ respectively and are listed in Table 6 . 
Table 6. Thermodynamic parameter for the adsorption of Fe(II) ion onto PONC

\begin{tabular}{ccccccccc}
\hline$\left(\mathrm{C}_{0}\right)$ & \multicolumn{4}{c}{$\Delta \mathrm{G}^{\circ}, \mathrm{kJ} / \mathrm{mol}$} & $\begin{array}{c}\Delta \mathrm{H}^{\circ}, \\
\mathrm{kJ} / \mathrm{mol}\end{array}$ & $\begin{array}{c}\Delta \mathrm{S}^{\circ}, \\
\mathrm{J} / \mathrm{Kmol}\end{array}$ & $\begin{array}{c}\mathrm{Ea}, \\
\mathrm{kJ} / \mathrm{mol}\end{array}$ & \multirow{2}{*}{$\mathrm{S}^{*}$} \\
\cline { 2 - 5 } & $30{ }^{\circ} \mathrm{C}$ & $40{ }^{\circ} \mathrm{C}$ & $50{ }^{\circ} \mathrm{C}$ & $60{ }^{\circ} \mathrm{C}$ & & \\
\hline 10 & -2758.4 & -3596.5 & -4150.3 & -4327.9 & 13.289 & 53.450 & 10523.4 & 0.0037 \\
20 & -3486.9 & -3809.0 & -4148.0 & -4794.3 & 9.3628 & 42.208 & 7722.77 & 0.0095 \\
30 & -2868.3 & -3239.4 & -3719.0 & -4039.8 & 9.2532 & 40.000 & 7267.69 & 0.0136 \\
40 & -2758.2 & -3115.8 & -3373.3 & -3670.8 & 6.3198 & 30.030 & 4867.65 & 0.0361 \\
50 & -2315.4 & -2508.1 & -2663.1 & -2953.6 & 3.9333 & 20.577 & 2868.56 & 0.0917 \\
\hline
\end{tabular}

From Table 6 it is clear that the reaction is spontaneous in nature as $\Delta G^{0}$ values are negative at all the temperature studied. Again positive $\Delta \mathrm{H}^{0}$ value confirms that the sorption is endothermic in nature. The positive value of $\Delta S^{0}$ reflects the affinities of the adsorbents for the $\mathrm{Fe}(\mathrm{II})$. The result as shown in Table 6 indicate that the probability of the $\mathrm{Fe}(\mathrm{II})$ to stick on surface of biomass is very high as $S^{*}<<1$, these values confirm that, the sorption process is physisorption ${ }^{24}$.

\section{Conclusion}

The adsorption of Fe(II) on to activated Posidonia oceanica nano carbon was investigated in this research work. The adsorption equilibrium well correlated with both Langmuir and BET isotherm models. The adsorption kinetic process was found pseudo-second-order model. Isotherm and kinetic study indicates that the PONC can be effectively employed for the adsorption of $\mathrm{Fe}(\mathrm{II})$ ions. Thermodynamic results show that adsorption of $\mathrm{Fe}$ (II) ions on to PONC was spontaneous and physical adsorption.

\section{References}

1. Amin N K, Desalination, 2008, 223(1), 152-161; DOI:10.1016/j.desal.2007.01.203

2. Amin N K, J Hazardous Mater., 2009, 165, 52-62; DOI:10.1016/j.jhazmat.2008.09.067

3. Gad H M and El-Sayed A A, J Hazardous Mater., 2009, 168(2), 1070-1081; DOI:10.1016/j.jhazmat.2009.02.155

4. Ganesh P S, Ramasamy E V, Gajalakshmi S and Abbasi S A, Biochem Engg J., 2005, 27(1), 17-23; DOI:10.1016/j.bej.2005.06.010

5. Garg V M, Amita M, Kumar R and Gupta R, Dyes Pigments, 2004, 63(3), 243-250; DOI:10.1016/j.dyepig.2004.03.005

6. Giri A K, Patel R and Mandal S, Chem Engg J., 2012, 185, 71-81; DOI:10.1016/j.cej.2012.01.025

7. Hameed B, Ahmad A and Latiff K, Dyes Pigments, 2007, 75(1), 143-149; DOI:10.1016/j.dyepig.2006.05.039

8. Hameed B A, Din M and Ahmad A, J Hazardous Mater., 2007, 141(3), 819-825; DOI:10.1016/j.jhazmat.2006.07.049

9. Pavan F A, Mazzocato A C and Gushikem Y, Bioresource Technology, 2008, 99(8), 3162-3165; DOI:10.1016/j.biortech.2007.05.067

10. Rahman M A, Amin S R and Alam A S, Dhaka University J Sci., 2012, 60(2), 185-189.

11. Arivoli S, Marimuthu V and Jahangir A R M, Inter J Bioassays, 2015, 4(01), (2015) 3611-3617.

12. Arivoli S, Rose Judith T and Marimuthu V, Eur J Appl Sci Technol [EUJAST], 2014, 1(1), 15-22.

13. Arivoli S, Rose Judith Tand Marimuthu V, Res Rev J Chem., 2014, 3(1), 15-22. 
14. Ho Y S and McKay G, Water Res., 2000, 34(3), 735-742; DOI:10.1016/S00431354(99)00232-8

15. Spark D L, CRC, Press, Boca Raton., 1986.

16. Weber T W and Chakravorti R K, J Am Inst Chem Eng., 1974, 20(2), 228-238; DOI:10.1002/aic.690200204

17. Hammed B H, J Hazardous Mater., 2009, 162(1), 305-311; DOI:10.1016/j.jhazmat.2008.05.036

18. Frendlich H, Z Phys Chem., 1906, 57, 385-470.

19. Langmuir I, J Am Chem Soc., 1918, 40(9), 1361-1403; DOI:10.1021/ja02242a004

20. Gupta G S, Prasad G and Singh V N, Environ Technol Lett., 1988, 9(12), 1413; DOI:10.1080/09593338809384708

21. Khan A A and Singh R P, Colloid Surfaces, 1987, (24), 33-42; DOI:10.1016/01666622(87)80259-7

22. Weber W J and Morris J C, J Sanitary Eng Div., 1964, 90, 79

23. Allen S J. Mckay G and Khader K Y H, Environ Pollut., 1989, 56(1), 39-50; DOI:10.1016/0269-7491(89)90120-6

24. Al Duri B, Mckay G, El Geundi M S and Wahab Abdul M Z, J Environ Eng Div ASCE, 1990, 116, 487. 